\title{
Е.К. КОЗЛОВ - РУКОВОДИТЕЛЬ, УЧЕНЫЙ, СОЗИДАТЕЛЬ: К 100-ЛЕТИЮ СО ДНЯ РОЖДЕНИЯ
}

\section{Макарова Е.И.}

Кольский научный центр РАH, Anamиты, makarova@admksc.apatity.ru

Евгению Константиновичу Козлову, чей 100-летний юбилей отмечает в 2018 г. научная общественность Кольского Севера, во многом выпало быть первым: первым ученым секретарем Кольского филиала АН СССР, первым директором института-первенца в структуре КФАН СССР Геологического института. Е.К. Козлов стал главным «прорабом» строительства научной структуры КФАН при председателе Президиума КФАН СССР А.В. Сидоренко - в 1950-е годы за неполные десять лет появились еще три института и базовые подразделения для будущих институтов, и он же принял «эстафету» руководства КФАН СССР в 1961 г., когда академик А.В. Сидоренко получил направление на руководящую работу в Правительство СССР.

Как никакой другой из нашей славной галереи лидеров и организаторов кольской науки Е.К. Козлов подходит под определение «герой своего времени»- времени стремительного роста науки и ее значения в экономике страны и региона, пришедшего на смену восстановительной послевоенной пятилетке, времени искренней веры населения страны в свое светлое Будущее на базе «мира, равенства и дружбы народов СССР». Сегодня можно с уверенностью утверждать, что история послевоенной науки на Кольском Севере - строительство Академгородка в г. Апатиты и развитие структуры Кольского филиала Академии наук тесно связаны с трудовыми подвигами «команды» А.В. Сидоренко, в которой Е.К. Козлов по праву занимал место единомышленника, друга и надежного помощника. Кто же он, герой кольской науки 1950-1960 гг.?

Евгений Константинович Козлов, один из руководителей Геологического института КФАН СССР в 50-е годы, председатель Президиума Кольского филиала АН СССР в 1961-1970 гг., родился в семье рабочих в г. Твери 1 декабря 1918 г. Мать, Евдокия Михайловна, 1894 г. рождения, работала ткачихой на фабрике им. Ваганова. Отец Константин Степанович, 1894 г. рождения, в гражданскую войну служил в Красной Армии, после окончания которой трудился в вагонном депо г. Калинина рабочим. Он рано ушел из жизни - в 1935 г. на 41-ом году жизни, оставив троих детей на попечении жены, которая, несмотря на невзгоды, смогла вырастить и дать всем троим детям высшее образование. Так, дочь Зинаида (1916 г.р.) и младшая дочь Людмила (1926 г.р.), стали преподавателями Калининского педагогического института и средней школы в г. Калинине, а сын, Е.К. Козлов - ведущим ученым и руководителем крупного научного учреждения. Тогда, в год смерти отца, Е. Козлов только окончил девять классов средней школы №1 г. Калинина, экстерном он получил аттестат зрелости и сразу же поступил на математический факультет Ленинградского государственного университета, но вскоре перевелся на геолого-почвенный факультет, почувствовав свое призвание к геологии. Там он встретил друга и соратника - Иванова А.М., с которым связала его судьба на долгие годы совместной работы на Кольской базе АН СССР, а затем в Кольском филиале АН СССР. Учителями Е.К. Козлова были выдающиеся ученые-академики Левингсон-Лессинг Ф.Ю., Полканов А.А., профессора Курбатов С.М., Судовиков Н.Г. и др., давшие глубокие знания и возможность выбора в качестве основного направления деятельности - научную работу. Е.К. Козлов был одним из лучших студентов университета, получив за все время учебы только одну четверку 
- «Анализу силикатов». В 1941 г. Е.К. Козлов окончил с отличием Ленинградский государственный университет, получив диплом по специальности «Геохимия, минералогия» и направление на работу в Кольскую Базу АН СССР. Но работу отсрочила Великая Отечественная война: с июня 1941 по февраль 1946 гг. Е.К. Козлов служил в действующей армии в составе в 7-й воздушной армии Карельского фронта.

В 1946 г. Е.К. Козлов демобилизовался и сразу поступил в аспирантуру при кафедре петрографии ЛГУ и, закончив ее в 1948 г., 19 мая 1949 г. успешно защитил диссертацию на тему «Петрология массива Сопчи в Монче», став кандидатом геолого-минералогических наук. Вместе с ним на Монче-тундре работала аспирантка Кольской базы АН СССР Т.Н. Иванова. В 1946 г. на полевых работах на Монче они поженились, а в 1948 г. у них родилась дочь Наталья, продолжившая в дальнейшем династию семейства геологов. 20 декабря 1948 г. Е.К. Козлов был зачислен на работу в КБАН СССР в должности м.н.с. Начиная с 20 июля 1949 г., Е.К. Козлов периодически исполнял обязанности ученого секретаря, в том же году был утвержден в должности старшего научного сотрудника. В июле 1950 г. назначен на должность заведующего отделом геологии КФАН СССР.

В 1950 г. в Кольский филиал АН СССР направлен А.В. Сидоренко - сначала на должность зам. председателя КФАН СССР, а после кончины

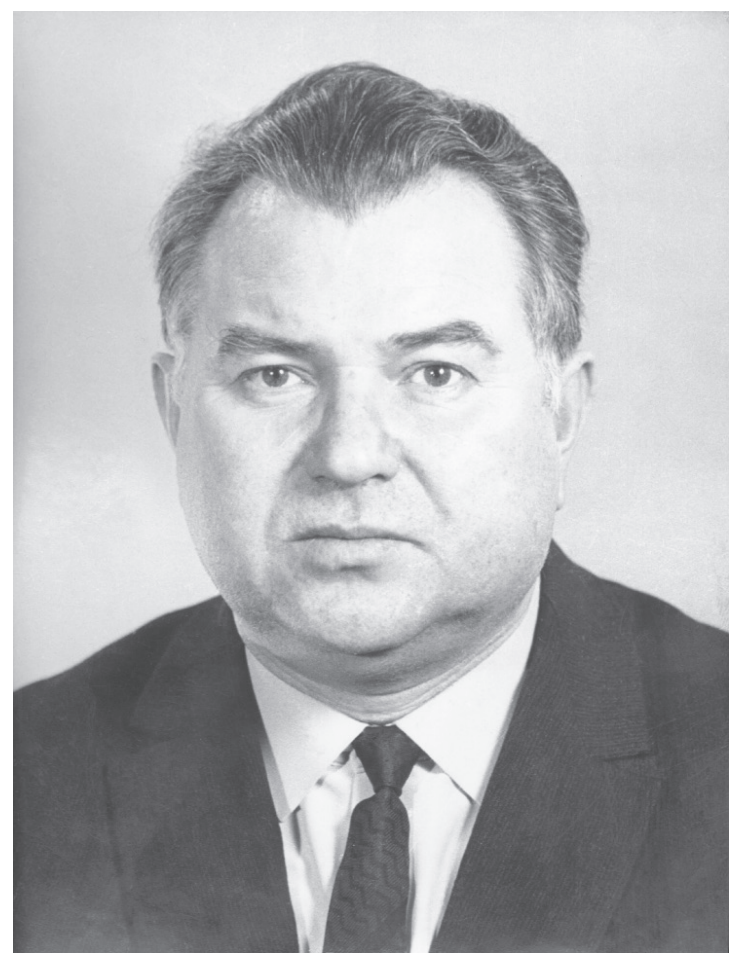

Козлов Е.К. председателя Филиала академика Д.С. Белянкина в 1952 г. - на должность председателя Президиума КФАН СССР. Оба бывшие фронтовики и геологи по профессии, А.В. Сидоренко и Е.К. Козлов сразу нашли общий язык в общем для них деле, и в спорте, и в различных общественных мероприятиях. 18 апреля 1952 г. на заседании Президиума КФАН СССР под председательством А.В. Сидоренко Е.К. Козлов был утвержден на должность первого директора Геологического института, которую занимал 10 лет - вплоть до нового назначения в 1961 гг. на должность председателя Президиума КФАН СССР. В июне 1952 г. у Е.К. Козлова родился сын Николай, продолживший путь отца в геологии, став его достойным преемником в науке, управленческой работе и сфере образования. Н.Е.Козлов прошел путь от младшего научного сотрудника до доктора наук, от заведующего лабораторией до директора Геологического института ФИЦ КНЦ РАН. Н.Е. Козлов, как и его отец, подарил стране двух геологов-сыновей, продолживших геологическую династию уже в третьем поколении.

К 1961 г. Геологический институт сформировался, как крупное региональное подразделение Академии наук, имеющее в своем составе 9 лабораторий и ряд вспомогательных подразделений. При постоянной поддержке председателя Президиума КФАН А.В. Сидоренко на базе подразделений Геологического института за неполные 10 лет в Филиале были созданы: институт Химии и технологии редких элементов и минерального сырья (1957); Горный институт (1960); Полярный геофизический институт(1960) и «базовые» подразделения для организации в отдаленном будущем других ныне действующих научных подразделений. К общему списку созданных институтов в структуре КФАН следует добавить Мурманский морской биологический институт, в 1958 г. преобразованный из МБС, присоединенной к Филиалу в 1953 г., а также Полярно-альпийский ботанический сад-институт, получивший статус института позднее (1966).[2, л.].

Возглавив в 1961 г. Президиум КФАН СССР, Е.К. Козлов не оставил важнейшее дело своей научной деятельности по изучению петрологии Мончегорского никеленосного плутона. На осно- 
ве полученных им данных были составлены рекомендации по направлению разведочных и поисковых работ в Мончегорском районе, которые использовались при составлении программ и перспективных планов поисково-разведочных работ на Кольском полуострове и которыми руководствовались геолого-разведочные организации. Е.К. Козлов опубликовал свыше 30 научных работ, в том числе 2 монографии; был научным руководителем многих аспирантов и соискателей на звание ученой степени, которые впоследствии стали кандидатами наук и ведущими учеными. В июне 1973 г. Е.К. Козлов успешно защитил докторскую диссертацию, но чтобы выполнить задуманное, ему пришлось отказаться от руководства Кольским филиалом. В своем обращении к Президенту АН СССР академику М.В. Келдышу от 23 февраля 1971 г. он обосновал свое решение так: «Глубокоуважаемый Мстислав Всеволодович! Последние двадцать лет мне приходится сочетать большую научноорганизационную работу с научно-исследовательской. Десять лет я руководил Геологическим институтом, а с 1961 г. - Кольским филиалом АН СССР. Проверка в феврале 1971 года ... комиссией Президиума АН СССР КФАН и его институтов показала, что научная и хозяйственная деятельность Филиала находятся в хорошем состоянии. За десять лет - с 1961 по 1971 год численность сотрудников Филиала выросла в три раза, основные фонды увеличились в четыре раза. Только за последнюю пятилетку 1966-1977 гг. Кольский филиал получил такое же развитие как за тридцать лет - с 1930 по 1960 гг. Все это потребовало от меня как от руководителя напряженной работы по организации служб, строительства и научной деятельности институтов Филиала... Сейчас для меня настал такой период, когда все силы надо сосредоточить на научных исследованиях... Поэтому убедительно прошу не представлять меня для избрания на должность председателя Президиума ...КФАН СССР на период 1971-1974 гг... Одновременно прошу выделить ... штатную единицу в ГИ зав. лабораторией петрографии, которой я руковожу двадцать лет на общественных началах, будучи директором ГИ, а затем председателем Президиума Филиала. Если возможно, прошу предоставить мне творческий отпуск на шесть месяцев для подготовки докторской диссертации...» [1, л. 149-150].

26 июля 1971 г. завлаб Е.К. Козлов ушел в творческий отпуск, позволивший завершить свой многолетний научный труд. Но годы напряжения взяли свое - через 10 месяцев после получения диплома доктора геолого-минералогических наук Е.К. Козлов ушел из жизни в возрасте всего 55 лет. В свидетельстве о смерти указаны четыре вполне смертельных диагноза, связанные с сердечной недостаточностью. Слишком близко принимал в свое большое сердце все проблемы и заботы о процветании кольской науки и Кольского Севера...

Сегодня можно с уверенностью утверждать, что историю послевоенной науки на Кольском Севере трудно представить без Е.К. Козлова. Создание Академгородка в г.Апатиты и развитие структуры Кольского филиала Академии наук - все это результаты труда «команды» А.В. Сидоренко, в которой Е.К. Козлов по праву занимал место надежного сподвижника и помощника. Память о нем живет в названиях улицы Козлова, которая плавно переходит в улицу Ферсмана, как бы опоясывая Академгородок, основное строительство и «обживание» которого пришлось, в основном, на годы руководства Филиалом Е.К. Козлова.

Военные и трудовые заслуги Е.К. Козлова отмечены правительственными наградами:

1. Медаль За оборону Советского Заполярья (14.04.1945)

2. «За победу над Германией» (18.02.1946)

3. Медаль «За трудовую доблесть» (28.05.1954)

4. Орден «Знак почета» Козлов Евгений Константинович (23.05.1963)

5. Медаль «20 лет победы в Отечественной войне 1941-1945 гг.» (08.11.1965)

6. Орден Трудового Красного Знамени (14.05.1966)

7. Медаль «50 лет Вооруженных сил» (08.08.1968)

8. Медаль «25 лет победы в войне 1941-1945 гг.» (ноябрь 1970)

9. Знаком «Отличник разведки недр»

10. Званием «Почетный гражданин города Кировска» (1970). [1. л. 107-108] 
В общей сложности Е.К. Козлов отдал 20 лет работе организатора кольской науки - 10 лет как директор Геологического институтом, 10 лет - как председатель Президиума Кольского филиала. При нем был, в основном, построен Академгородок, еще до того, как Новый город получил статус и имя города Апатиты (1966). Можно смело предположить, что Академгородок и запланированный переезд КФАН СССР на новое место во многом определил будущее города Апатиты как культурного центра на Кольском Севере, и «очага» науки и образования в XX-XXI столетии.

\section{Литература}

1. Личное дело Евгения Константиновича Козлова (1941-1974). Научный архив ФИЦ КНЦ РАН. Ф. 1. Оп. 18. Д. 1267. Л. 1-161.

2. Петров В.П., Макарова Е.И., Саморукова А.Г., Токарев А.Д., Усов А.Ф. Кольский научный центр. Летопись 1930-2010. Апатиты: Изд. КНЦ РАН, 2011. С. 77-103. 